\title{
Effect of exchange rate movements on Ghanaian banks
}

\author{
Albert Amponsah Addae ${ }^{1,}$, , Michael Nyarko-Baasi ${ }^{1}$, Michael Lawer Tetteh ${ }^{2}$ \\ ${ }^{1}$ Methodist University college Ghana, Department of Banking and Finance, Box DC 940 Dansoman- Accra \\ ${ }^{2}$ School of Business, Zenith University College, Ghana
}

\section{Email address:}

shinalberto@gmail.com (A. A. Addae), aaddae@mucg.edu.gh (A. A. Addae), mnbaasi@yahoo.com (M. Nyarko-Baasi), michaellawer@gmail.com (M. L. Tetteh)

\section{To cite this article:}

Albert Amponsah Addae, Michael Nyarko-Baasi, Michael Lawer Tetteh. Effect of Exchange Rate Movements on Ghanaian Banks. Journal of Finance and Accounting. Vol. 2, No. 3, 2014, pp. 62-71. doi: 10.11648/j.jfa.20140203.15

\begin{abstract}
The main purpose of this paper is to look at the exchange rate sensitivity of some listed banks on the Ghana Stock Exchange (GSE) between 2005 and 2010. In order to achieve the purpose, we adopted both quantitative and qualitative approaches. Econometric models were employed to deal with both the exchange rate sensitivities and to ascertain the exchange rate exposure of the Banks. The study discovered that all the banks studied engage in forex trading and made gains/profits from such activities. It was further found that apart from Ghana Commercial Bank and Standard Chartered Bank who were exposed to foreign exchange risk - pound sterling, the rest of the banks had no exposure to any of the currency risk. All the banks on the other hand have risk management structures in place to mitigate any risks that arise as a result of their operations. The overall interest in risk management by the banks is very high as they have put in some financial derivative measures to mitigate any exchange rate risk that they are exposed to.
\end{abstract}

Keywords: Exchange Rate, Foreign Exchange Risk, Ghana Stock Exchange

\section{Introduction}

The sensitivity and impact of exchange rate movements are real and vital to the position of any financial entity. This is due to the translational risk that affects stock prices through their fundamental impacts on firms' expected cash flows through the equity values to the exchange rate changes (Carrieri and Majerbi, 2006). The firm operating in the international environment will be affected in one way or the other by changes in the exchange rate variations between different currencies. The degree to which a firm is affected by such changes is called foreign exchange exposure and its measures take one of two forms. Either they can involve changes in real economic values or they can involve hedging strategies (Booth, 1982). The purpose of this study however, is embedded in the economic value premise as a result of foreign exchange exposure of listed banks on the Ghana Stock Exchange (GSE). The return on the stock is the rate of return/profitability or equity income for a firm's portfolio and provides a useful way to measure how exchange rates affect the value or economic exposure of firms (Allayannis and Ihrig, 2001). This is particularly important since the foreign exchange risk exposure of a firm is related and affects the cash flows and, subsequently, the market value of the firm either positively or negatively (Booth, 1982; Miller and Reuer, 1998b; Salifu et al., 2007).

Foreign exchange risk management has become increasingly important since the abolishment of the fixed exchange rate system of Bretton Woods in 1971 when it was replaced by a floating rates system in which the price of currencies is determined by supply and demand of money and can be said to contribute to currency fluctuations (Abor, 2005). This in a way can affect foreign direct investments (FDI) and foreign investments for that matter. As noted by Carrieri and Majerbi (2006), capital flows into emerging markets (EMs) have increased sharply in recent years, signaling a renewed interest by international investors in the assets of these countries but the practical question still remains as to whether foreign exchange risk is priced in the stock market of these emerging markets? It is also asserted that emerging markets such as Ghana offer valuable diversification potential to international investors, but at the same time they tend to be characterized by large exchange rate uncertainty or volatility, including the risk of devaluation for countries with fixed or pegged exchange rate regimes Carrieri and Majerbi (2006).

It must be added also that the current high volatility being experienced in the foreign currency market in Ghana, makes it more risky for foreign exchange transactions. 
Taking a critical look at one of the core banking operations which is to serve as trade intermediaries and also as deficit financiers, they are bound to face exchange rate risk to a very high extent and more so with the those banks with multinational dimensions. Bradley and Moles (2002) believe that, multinational firms with operations in several countries will have spill over risks from having assets and liabilities denominated in foreign currencies. However, the extent of the effect of the currency exposure sometimes face the tough question as to whether the effect of currency risk on an emerging market (example the GSE) will have any meaningful effect on a particular market system where subsidiaries of multinational firms exist. More importantly, it is often questioned in certain quarters (see Carrieri et al., 2006) as to whether emerging market risks affect the broader global capital market. Although theoretical models would suggest that the currency risk stemming from these markets (emerging markets) might be of limited importance since such markets represent a small component of the world market capitalization, the issue of whether the price of foreign exchange risk and the extent of its global economic relevance is to a large extent an open empirical question (Carrieri et al., 2006).

The main purpose of this paper is to look at the exchange rate sensitivity of some listed banks on the Ghana Stock Exchange (GSE) between 2005-2010. As a precondition to the broader aim, we seek to; assess the gains made by the banks from foreign currency trading over the study period, find whether the banks are exposed to any currency risk by way of estimating the exposure of the banks being studied to the major trading currencies in Ghana in relation to their stock returns, find out how the banks manage their exchange rate risks and assess how some macroeconomic indicators affect the economic position of the banks

\section{Empirical Review}

Economic theory postulates that under a floating exchange rate regime, changing exchange rates affect the competitiveness of firms, especially those engaged in international trade. Home currency depreciation promotes the competitiveness of firms in home country by allowing them to undercut prices charged for goods manufactured abroad (Luehrman, 1991). On the other hand, exchange rate appreciation reduces the competitiveness of export markets and therefore has a negative effect on the domestic stock market. Conversely, if the country is import denominated such as in the case of Ghana, exchange rate appreciation may have positive effect on the stock market by lowering input costs. Thus, an increase in the value of the home country firm in response to a real drops in the value of the home currency. The reverse also hold.

A considerable number of studies aimed at testing the foregoing propositions have been conducted to determine the exposure of firms to exchange rate movements (Mention a few here). Not only do these studies have been inconclusive on the nature of exchange rate exposure, they have been largely conducted on industrialized economies. In what follows, we undertake a review of the extant literature on exchange rate exposure. Jorion (1991) conducted an empirical investigation on the sensitivity of the stock prices of US multinationals to changes in dollar exchange rates. His empirical results indicated that the sensitivity of stock prices to changes in exchange rate is not significant at any accepted level of significance. Luetherman (1991) tested the hypothesis that an exogenous real home currency depreciation enhances the competitiveness of home country manufacturers vis-a-vis foreign competitor. His finding did not support that hypothesis. Firms did not benefit from a depreciation of the home currency. On the contrary, a significant decline in their market share was found as a result of depreciation of the home currency. Bodnar and Gentry (1993) examined the relationship between exchange rate changes and industry portfolio returns for Canada, Japan and the United States between 1979 and 1988. The study revealed that less than half of the industries display significant exchange rate exposure at the $10 \%$ significant level in these countries. AlDiab, Zoubi, and Thornton (1994) examine the impact of changes in the dollar exchange rate on daily security returns of US multinational companies. The study made use of an event study methodology for the period 1978 to 1987 , and concluded that the stock prices of Multinational Companies are not greatly affected by changes in exchange rates or that the relationship is weak.

Donnelly and Sheehy (1996) examined the relationship between changes in trade-weighted nominal exchange rate and the monthly abnormal returns of portfolio of the UK's 39 largest exporting firms during the period 1978 to 1992. The study finds a contemporaneous negative relationship between the foreign exchange changes and the abnormal returns of UK exporters. Fang and Loo (1994) investigated the effect of unanticipated changes in the US tradeweighted exchange rate on US industries' common stock returns over the period 1981 to 1990 . The study recorded significant negative betas for the mining, food and beverage, chemical, petroleum and utilities industries, whereas, positive exchange rate risks betas are observed in retail and apparel, machinery, transportation equipment, department stores, and miscellaneous industries. Glaum, Brunner and Himmet (2000) examined the economic exposure of German corporations to change in DM/US dollar exchange rate. They found that German firms are significantly exposed to changes in DM/US dollar rate. Krishnamoorthy (2001) examines whether the industrial structure is an important determinant of the exchange rate exposure of US industry portfolio returns over 1995-1997 period. The study indicated that industries that are classified as being globally competitive and those that serve the consumer sector of the economy have significant levels of exposure. Chang (2002) used the two-factor model of Jorion (1990) to examine industry-level currency risk of Taiwan's stock market around the Asian financial crisis. Conclusions from the study indicated that export- 
oriented industries are positively affected by the depreciation of the Taiwan dollar against the US Dollar. The results further show that there is a negative relationship between firm size and currency exposure in Taiwan's stock market, thus finds support for the hypothesis that the exchange rate risk is less for larger firms than for smaller firms as documented by studies such as Nance, Smith and Smithson (1993) and Chow, Lee and Solt (1997). Joseph (2002) examined the impact of foreign exchange rate changes and interest rate changes on UK firms during the period 1988 to 2000 . He considers two different measures of foreign exchange rate impacts, along with a measure of interest rate changes. The findings show that industry returns are more negatively affected by interest rate changes than by foreign exchange rate changes.

The only study, to our knowledge that explains the exchange rate exposure of firms from an African perspective is that of Zubeiru, Kofi and Adjasi (2007) for Ghanaian firms. They examined the foreign exchange exposure of listed companies on the Ghana Stock Exchange over the period January 1999 to December 2004. The research uses different exchange rate measures namely; the cedi to US dollar, the cedi to UK pound sterling, the cedi to the euro and a trade-weighted exchange rate index to determine the degree of exposure. The Jorion (1990) twofactor model which regresses the return on a firm against changes in the exchange rate and return on the market was used to estimate the exchange rate exposure for the sample of twenty firms used in the study. About 55 per cent of firms in the sample have a statistically significant exposure to the US dollar whilst 35 per cent are statistically exposed to the UK pound sterling. Sector specific exposure results show that the manufacturing and retail sectors are significantly exposed to the US dollar exchange rate risk. The financial sector did not show any risk exposure to any of the international currencies. The most dominant source of exchange rate risk exposure is the US dollar. Most firms are also negatively exposed to the cedi to US dollar exchange rate changes, implying that the cedi depreciation vis-a-vis the US dollar adversely affects firm returns.

\section{Methodology}

\subsection{Estimation Procedure}

In order to achieve all the set objectives of this paper, we adopted both quantitative and qualitative approach to the paper. For the purpose of estimating our exchange rate sensitivities or in order to ascertain the exchange rate exposure of the banks, two econometric models were employed as shown in equations 2.1.1 and 2.1.2 below. In all, the study settled on three currencies namely; the US Dollar, the UK Pound, and the European Euro. These are the three major trading currencies in Ghana and are therefore deemed appropriate to effectively help us achieve the papers' intended purpose. These three currencies were chosen as exchange rate proxies for the Ghana Cedi because most of the international trade volumes between Ghana and her trading partners are transacted based on these currencies with the dollar dominating the means of trade most of the time.

$R_{i t}=\beta_{0}+\beta_{1 i} U S D_{t}+\beta_{2 i} U K P_{t}+\beta_{3 i} E U R O_{t}+\lambda_{i}+\mu_{i t}(3.1 .1)$

where; $R_{i t}=$ Return on the stock of firm $i$ at time $t$, $\beta_{0}=$ The constant term, $\beta_{1}, \ldots, \beta_{n}=$ The coefficients/sensitivities of the explanatory variables, $U S D_{t}=$ Percentage change in the US dollar in relation to the Ghana cedi at time $t, U K P_{t}=$ Percentage change in the $U K$ pound in relation to the Ghana cedi at time $t$, Euro E $_{t}=$ Percentage change in the Euro in relation to the Ghana cedi at time $t, \lambda_{i}=$ unobservable individual time effect and, $\mu_{i t}=$ The error term.

According to Miller and Reuer, (1998a) because other macroeconomic variables co-vary with exchange rate movements which in reality or as is being witnessed presently in the Ghanaian context, failure to include them in an exposure model could result in exaggerated estimates of the proportion of variance in stock returns attributable to foreign currency movements. Hence, in addition to estimating the exposure model in equation (3.1.1), we also specified a model of corporate exposure equation (3.1.2) that controlled for percentage changes in macroeconomic indicator (interest rates) by using the 90-day Treasury-bill rate as a proxy and returns to the overall stock market portfolio. The second model that incorporates the other control variables is specified as follows:

$$
\begin{gathered}
R_{i t}=\beta_{0 i}+\beta_{1 i} U S D_{t}+\beta_{2 i} U K P_{t}+\beta_{3 i} E U R O_{t}+ \\
\beta_{4 i} R m_{t}+\beta_{5 i} r_{t}+\lambda_{i}+\mu_{i t}
\end{gathered}
$$

where; $R m_{t}=$ Overall market portfolio return in month $t$, $r_{t}=$ Percentage change in the real interest rate at time $t$

\subsection{Data Source and Collection Methods}

Purposive sampling was adopted for the study. Purposive sampling technique, also called judgment sampling, is the deliberate choice of a respondent/unit due to the qualities the individual/entity possesses (Tongco, 2007). The technique was applied to the study to select the sample in view of the fact that, the sample units had to be banks listed on the GSE and had to meet all the data requirements of paper. In all, a sample of six (6) listed banks formed the sample size for the paper over a six year period between 2005-2010.

For the returns on the stocks of the listed banks and the returns on the market, monthly secondary data was sourced from the Ghana stock Exchange (GSE) on all the banks. While the ones bordering on the three foreign exchanges (US Dollar, UK Pound, and Euro) to the Cedi and the treasury-bill rate was obtained from the Bank of Ghana. Regarding the primary data, interviews were conducted with at least one forex trading officer for each of the banks. Careful and relevant notes were then taken to help answer some of the questions raised. 


\section{Results and Discussion of Findings}

The main aim of data analysis is to provide meaningful information about the phenomenon under investigation that will enable useful analysis and also process and display data for ease of drawing conclusions.

\subsection{Sensitivity Analysis}

\subsubsection{Sensitivity of Bank Returns to Exchange Rate Risk}

The sensitivity and impact of exchange rate movements are key to the position of any financial entity as it affects firms' expected cash flows through the equity values to the exchange rate changes (Carriei and Majerbi, 2006) and also provides a useful way to measure how exchange rate affects the value or economic exposure of firms. Foreign exchange risk exposure is the risk that an entity will be required to pay more or less than expected as a result of fluctuations in the exchange rate between its currency and the foreign currency in which payments must be made. In this paper, stock returns served as the proxy for firm earnings while foreign exchange rate sensitivity/exposure of the banks were estimated aside other macroeconomic factors that have shown in the foreign exchange risk literature to affect the exchange rate risk position of banks. To do this, we employed an econometric model to estimate and measure the degree/extent of the exposure of the banks to the major trading currencies in Ghana.

\subsubsection{Sensitivity/Exposure of CAL Bank}

The results from our first econometric model as shown in table 1 give mixed result as to which bank is exposed to what kind of foreign exchange. Looking at the regression results for Cal Bank (CAL), we can observe that at the 10 percent, 5 percent, and 1 percent significance levels, the bank is not exposed to any of the major foreign currencies used in Ghana which are the US dollar, the UK pound, and the Euro. The insensitivity of the bank to the major exchange rates could be that either the bank has in place measures to either eliminate or reduce their risk exposure such as hedging or by employing the traditional buying and holding approach. In terms of model performance, the model recorded an $\mathrm{R}^{2}$ value of 0.10 meaning that only 10 percent of the variation in the stock return of the bank is explained by the fluctuations in the dollar, pound, and the Euro. Nonetheless, the model is fit and significant at the 0.10 alpha level with an F-statistic of 2.64.

\subsubsection{Sensitivity/Exposure of GCB}

Ghana Commercial Bank (GCB) showed some level of sensitivity to the UK pound as compare to CAL bank. From the table (table 1), the bank is exposed to the fluctuations of the pound at a both the 10 and 5 percent significant levels but not to the dollar and euro. This result is somehow surprising since the dollar is the major means of transacting international trade and business and for that matter it is expected to pose much treat as opposed to the dollar. Notwithstanding this outcome, it must be remembered that as found by Abor (2005), due to little development in the foreign exchange derivative market in Ghana, most firms rely on the classical buying and holding methodology as a measure of cushioning their exposure to exchange rate shocks. By inference, we can say that the bank had cushioned itself against the other foreign currencies but was exposed to the pound. The exposure is also a positive one thus by the coefficients, implying that stock returns appreciated with depreciation in the value of the cedi relative to the UK pound. It therefore appears that if the bank had transacted much of its transactions in the UK pound, it would have benefited by using this currency in their international transactions.

The constant of the model is also significant at the 10 percent significance level meaning that when all the other coefficients of the variables are zero (0), the model will be equal to the constant. The overall model fit per the $\mathrm{R}^{2}$ of 0.14 and the F-statistic of 2.64 shows an overall model fit at the 10 percent level.

\subsubsection{Sensitivity/Exposure of HFC Bank}

The next bank under discussion is HFC bank. The result indicates an insensitivity of the bank to any of the three foreign currencies. It could be that the bank is applying some kind of derivative of a sort. According to Salifu et al. (2007), despite the existence of numerous derivative instruments such as balance sheet hedging, use of derivatives, leading and lagging, swaps amongst others, their applications appear to be sophisticated and difficult to implement in developing countries like Ghana hence their popularity in the developed world. In that instance, it is intuitive to infer that the bank might be applying one of the techniques as shown by Abor (2005) which include the use of price adjustments to reflect balance sheet changes and the buying and holding of foreign currency. The ability of the exchange rate fluctuations to explain the changes in the value of the bank (HFC) accounted for just 19 percent. This means that other factors other than exchange rate risk, account for the rest of the 81 percent with a significant level of 0.0025 which is significant at the 0.10 and 0.05 alpha levels.

\subsubsection{Sensitivity/Exposure of SCB}

Similar to the result of GCB, Standard Chartered Bank (SCB) is exposed to foreign exchange rate risk specifically, the pound. This is positively and statistically significant at both the 10 percent and 5 percent significant levels meaning that the value of the firm appreciated in the same period as the cedi depreciated against the pound. This shows cash flow advantages to the bank since it would have benefited from the appreciation in its value in relation to its international transactions using the pound. The findings of this present study corroborates that of Salifu et al. (2007) who found that firms with exposure to the UK pound experienced higher stock returns as the cedi depreciated against the UK pound leading them to affirm that it is advantageous for listed firms on the Ghana Stock Exchange (GSE) to denominate their international transactions to the UK pound. On the contrary, the firm is 
not exposed to the dollar and the euro. The model on the whole, recorded an impressive 36 percent variation in the stock returns in relation to the changes in the foreign exchange rates. This fit is as well significant at the 0.01 , 0.05 , and the 0.10 alpha levels with an F-value of 6.37 indicating that the combined effort or risk of the three exchange rates can affect the returns of the bank's stock.

\subsubsection{Sensitivity/Exposure of SG-SSB and TBL}

The Social Security Bank (SSB) now SG-SSB and the Trust Bank (TBL) are not sensitive to the fluctuations of the exchange rate market at the 10 percent, 5 percent, and 1 percent significant values as can be seen from their probability values in table 1 . Nonetheless, the two models;
SSB and the TBL models are significant. The SSB model is significant at the 1 percent, 5 percent, and 10 percent levels while the TBL model is fit at the 0.10 alpha level with $\mathrm{R}^{2}$ 26 percent and 10 percent respectively. These results mean that even though the value/returns of the two banks are to some extent influenced by the combined effect of the dollar, pound, and the euro, their singular effects are insignificant to expose the banks to any currency risk. This is particularly important since the foreign exchange risk exposure of a firm is related and affects the cash flows and, subsequently, the market value of the firm either positively or negatively.

Table 1. Estimation Results showing the sensitivity of Banks to foreign Exchange.

\begin{tabular}{lllccll}
\hline Banks & Constant & US Dollar & UK Pound & Euro & $\mathbf{R}^{2}$ & F-Statistic \\
\hline \multirow{2}{*}{ CAL } & 0.0243 & 9.8070 & -12.3852 & -22.3072 & 0.1042 & 2.64 \\
& $(0.308)$ & $(0.852)$ & $(0.141)$ & $(0.677)$ & & $(0.0566)$ \\
GCB & -0.0803 & 42.9362 & 47.9912 & 5.4006 & 0.1409 & 3.72 \\
& $(0.057)$ & $(0.640)$ & $(0.002)$ & $(0.954)$ & & $(0.0154)$ \\
HFC & 0.0018 & -25.462 & -2.2935 & 23.3744 & 0.1888 & 5.28 \\
& $(0.822)$ & $(0.157)$ & $(0.421)$ & $(0.202)$ & & $(0.0025)$ \\
SCB & -0.0141 & 3.0873 & 8.4253 & 5.4533 & 0.3451 & 6.37 \\
& $(0.221)$ & $(0.903)$ & $(0.039)$ & $(0.832)$ & & $(0.0004)$ \\
SSB & -0.0134 & 46.4788 & 7.5536 & -39.6162 & 0.2563 & 5.92 \\
& $(0.606)$ & $(0.418)$ & $(0.409)$ & $(0.498)$ & & $(0.0013)$ \\
TBL & -0.0011 & 0.7529 & 0.6806 & -0.07186 & 0.1005 & 2.34 \\
\end{tabular}

Note: The values in parenthesis represent probabilities

\subsection{Sensitivity to Exchange Rate Risk}

Interest rate and market return were introduced into the regression analysis to see if they will influence the exposure of the firms to currency risk. The result in table 2 does not show any significant difference from that of table 1 in terms of the exposure of the various banks to the US dollar, UK pound, and the Euro. The only banks exposed to foreign exchange rate risk in the second model are GCB and SCB. These banks are both positively exposed to the UK pound meaning that both banks would have had good cash flows and increment in their firm values as well as favourable international transactions during this time as their stock returns appreciated in the same period as the cedi depreciated against the UK pound. GCB's exposure is significant at the 1 percent, 5 percent, and 10 percent significant levels while that of SCB is significant at the 0.05 alpha level. This finding finds support from the study results of Miller and Reuer (1998a) that including controls for market returns and interest rate movements, does little to alter the proportion of firms exposed to exchange rates indicating that the proportion of firms exposed to movements in these foreign exchange rates does not depend on the inclusion or exclusion of market and interest rate controls in the case of listed banks on the GSE.

Certainly, the inclusion of interest rate and market returns did not affect the exposure of the banks. However, one bank was sensitive to interest rate movements. From table 2, only SCB is influenced by interest rate movements and it is positively significant at the 0.05 alpha level. What this means is that, there is a positive correlation between the value of SCB or its stock returns and the local interest rate indicating that under such conditions, investors consider a foreign investment as riskier, perceiving exchange risk as a real currency risk and hence invest in the local stock as it is expected to yield a better returns. Investors do contrariwise only if they expect some compensation in terms of expected returns when investing in foreign stock markets (Carrieri and Majerbi, 2006).

As expected, all the banks have significant and strong positive correlation with the overall market return at the 1 percent, 5 percent, and 10 percent significant levels. The inclusion of the control variables also improved the model fit of all the banks. 
Table 2. Sensitivity Analysis of the Banks when Market Returns and Interest Rateare Included.

\begin{tabular}{|c|c|c|c|c|c|c|c|c|}
\hline Bank & Constant & US Dollar & UK Pound & Euro & Interest Rate (r) & Market Return (Rm) & $\mathbf{R}^{2}$ & F-Statistic \\
\hline CAL & $\begin{array}{l}-0.0082 \\
(0.606)\end{array}$ & $\begin{array}{l}15.8230 \\
(0.663)\end{array}$ & $\begin{array}{l}6.7188 \\
(0.233)\end{array}$ & $\begin{array}{l}-9.2977 \\
(0.795)\end{array}$ & $\begin{array}{l}-0.2412 \\
(0.979)\end{array}$ & $\begin{array}{l}0.8940 \\
(0.000)\end{array}$ & 0.3139 & $\begin{array}{c}6.04 \\
(0.0001)\end{array}$ \\
\hline GCB & $\begin{array}{l}-0.0855 \\
(0.033)\end{array}$ & $\begin{array}{l}11.2854 \\
(0.901)\end{array}$ & $\begin{array}{l}51.8352 \\
(0.000)\end{array}$ & $\begin{array}{r}30.7639 \\
(0.730)\end{array}$ & $\begin{array}{l}11.0019 \\
(0.629)\end{array}$ & $\begin{array}{l}1.4797 \\
(0.003)\end{array}$ & 0.2511 & $\begin{array}{c}4.43 \\
(0.0015)\end{array}$ \\
\hline $\mathrm{HFC}$ & $\begin{array}{l}0.0018 \\
(0.825)\end{array}$ & $\begin{array}{c}-26.8179 \\
(0.157)\end{array}$ & $\begin{array}{l}-2.1958 \\
(0.451)\end{array}$ & $\begin{array}{c}23.7659 \\
(0.203)\end{array}$ & $\begin{array}{l}1.1143 \\
(0.814)\end{array}$ & $\begin{array}{l}0.3476 \\
(0.056)\end{array}$ & 0.1897 & $\begin{array}{c}3.09 \\
(0.0144)\end{array}$ \\
\hline SCB & $\begin{array}{l}-0.0140 \\
(0.207)\end{array}$ & $\begin{array}{c}-15.6111 \\
(0.537)\end{array}$ & $\begin{array}{l}9.6987 \\
(0.015)\end{array}$ & $\begin{array}{l}10.088 \\
(0.685)\end{array}$ & $\begin{array}{l}16.0738 \\
(0.013)\end{array}$ & $\begin{array}{l}0.3051 \\
(0.008)\end{array}$ & 0.2077 & $\begin{array}{c}3.46 \\
(0.0077)\end{array}$ \\
\hline SSB & $\begin{array}{l}-0.0170 \\
(0.487)\end{array}$ & $\begin{array}{l}31.5223 \\
(0.575)\end{array}$ & $\begin{array}{l}9.7334 \\
(0.264)\end{array}$ & $\begin{array}{c}-23.8709 \\
(0.666)\end{array}$ & $\begin{array}{l}1.7200 \\
(0.903)\end{array}$ & $\begin{array}{l}0.9624 \\
(0.002)\end{array}$ & 0.1531 & $\begin{array}{c}2.39 \\
(0.0473)\end{array}$ \\
\hline TBL & $\begin{array}{l}-0.0124 \\
(0.175)\end{array}$ & $\begin{array}{l}1.9229 \\
(0.927)\end{array}$ & $\begin{array}{l}1.9220 \\
(0.551)\end{array}$ & $\begin{array}{l}0.2547 \\
(0.990)\end{array}$ & $\begin{array}{l}-0.2659 \\
(0.960)\end{array}$ & $\begin{array}{r}0.2186 \\
(0.0523)\end{array}$ & 0.1465 & $\begin{array}{c}2.09 \\
(0.0685)\end{array}$ \\
\hline
\end{tabular}

Note: The values in parenthesis represent probabilities

\subsection{Gains/Losses from Forex Activities of Banks}

From this paper, we observed that all the banks under study engage in foreign exchange business. This activity contributes immensely to the operating income of these banks and it appears that some of the banks are taking an advantage of the huge prospects in the area despite its potential risks to boost their profitability. The trends in this activity by each of the banks assessed is shown in figure 1 below. From the graph, it is clear that not all the banks are visible in terms of their earnings power from this activity whiles others clearly announces their presence.

From the figure 1, it can be seen that Ghana Commercial Bank (GCB) poses a striking picture and had the highest gain of GHS10,500,824 in the year 2009. This outcome is not surprising given that GCB is one of the big sized banks in the country currently and was the biggest as at 2009 . Looking at the profit/loss trend of the bank, it is evident that the banks performance grew considerably from 2005 up to GHS10,500,824 in 2009. But then despite the huge gains, the bank recorded a loss from exchange trading at the end of the year 2010 of GHS 3,091.

Another bank that showed an impressive trend is SGSSB. From the figure, it is clearly visible that the bank has had some ups and downs in profit between 2007 and 2009. Nonetheless, the profitability of the trading activity took an upward trend in 2010 to a height of 5,723,807. Similarly, HFC bank is also showing signs of gains after a deep in 2007 and it's trending upwards. From the look at the graph (Figure 1), it suggests that only these three banks have substantial gains from the forex trading activity. We can therefore describe them as the most active traders while Cal bank, Standard Chartered bank and Trust bank (Gambia) seem to trending on a rather horizontal path.

In general, it can be said that the risks involved in this activity is huge and so is the gain/loss. As can be seen from the position of GCB as at 2010, it made significant losses after an impressive gain in the previous year. This can however be likened to the risk-return premise. However, each bank has its own risk appetite and risk management framework and so, it must not be expected that all the banks will take the same risks.

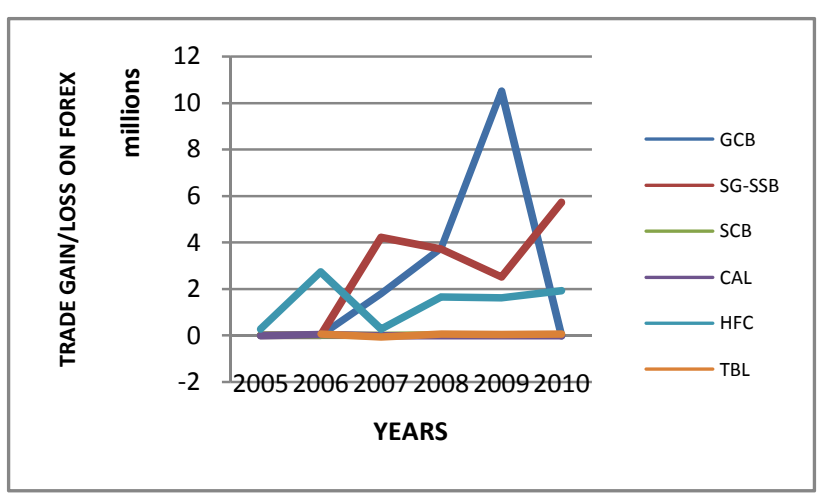

Figure 1. Forex Trading Activity of Banks.

\subsection{Exchange Rate Risk Management Practices by the Banks}

\subsection{1. $S G-S S B$}

The foreign exchange risk faced by banks affects their financial position and cash flows. The Bank is exposed to the following risks: credit, liquidity, interest rate, market and other operational risks. Market risk is the risk of losses being incurred as a result of adverse movements in the interest or exchange rates and rises in the banks treasury activities. The risks inherent in the Bank's activities are managed through a process of ongoing identification, measurement and monitoring, subject to risk limits and other controls. This process of risk management is critical to the Bank's continuing profitability and each individual within the Bank is accountable for the risk exposures relating to his or her responsibilities. The Board of Directors is responsible for the overall risk management approach and for approving the risk management strategies and principles. Market risk is controlled by interest mismatch and foreign currency open position limits approved by the executive committee of the bank and monitored on daily basis as well as the use of forwards and swaps.

In addition, there are Risk Committees that have the overall responsibility for the development of the risk strategy and implementing principles, frameworks, policies and limits. From these practices in the bank, we can say 
that there are clear and laid down risk management procedures which show ways of identifying risks and ways of managing them. Further enquiry also showed that the bank has already started implementing its hedging decisions in the foreign exchange market against their foreign exchange rate risks by taking up forex forward contracts or swap contracts. Though such forex derivative products have been available in Ghana for years, it has not been widely utilized. The report from the interview also shows that derivative strategy has been worth taking as evident from the results of the sensitivity analysis of the bank.

\subsubsection{Ghana Commercial Bank}

As one of the major industry players, the Bank has exposure to the following types of risks from its use of financial instruments: Credit Risk, Liquidity Risk, Market Risk, and Operational Risk. According to the bank however, these risks are managed professionally and in a targeted manner. Key risks arising from core functions are identified and measured to facilitate managing and determining risk positions and capital allocations. It was also gathered from the interview that the Bank continues to assess its main risks and is in the process of enhancing its overall risk management framework and governance structure as changes to regulations in the banking sector reinforce the Bank's commitment to embed enhanced risk based cultures throughout the organization. It was further noted that the Bank is in the process of upgrading its risk management processes and governance structures to ensure they favorably compare to those of leading international banks.

As a commitment to this process, the bank has a robust risk management framework in place where the Board of Directors has overall responsibility for the establishment and oversight of the Bank's risk management. In addition, there is a Risk Management Division (RMD) and Committee are responsible for developing and monitoring the Bank's risk management policies over specified areas. These committees report regularly to the Board on their activities through the Executive Management Committee. Taking an entrenched position to proper risk management implementation, it is clearly understood by the Directors of the Bank that they are ultimately responsible for ensuring that risk management is properly and adequately enforced throughout the organization and are committed to managing risks based on the levels of exposure they present.

\subsubsection{Standard Chartered Bank}

The officer interviewed clearly indicated that the bank is exposed to credit risk, cross-country-border risk, market, liquidity, operational, regulatory, pension, and reputation risks. Narrowly, the Bank's foreign exchange exposures comprise of both the trading and non-trading foreign currency translation exposures which are principally derived from customer driven transactions.

In terms of risk policies, the bank aims to obtain the optimal balance of risk and return whilst meeting customers' requirement. In that regard, the bank has a defined risk appetite (the amount of risk that the bank is prepared to take) which enables the bank to stay within its acceptable risk limits. On risk monitoring aspects, the bank conducts periodic stress tests to ensure that it is operating within their acceptable risk limits. As a currency risk strategy, the officer interviewed disclosed that the bank engages in currency swaps as a derivative instrument for currency risk hedging. This instrument could have accounted to the reasons why the bank was not exposed to the dollar and the euro when the banks' sensitivity to exchange rate risk was evaluated or analysed.

\subsubsection{CAL Bank}

It was evident that the bank is exposed to risks such as; credit risk, liquidity risk, market risks, and operational risks. In terms of risk management structure, the Board of Directors has overall responsibility for the establishment and oversight of the risk management framework of the bank. The risk management committee of the board assists the Board in carrying out this responsibility. To enable it achieve its purpose, the Committee reviews and monitors aggregate risk levels in the business and the quality of risk mitigation and controls for all areas of risk to the business, makes recommendations to management on areas of improvement, and informs the Board of progress in implementing improvements.

The Board has also established the Asset and Liability Management Committee (ALCO) and Risk Management Department which are responsible for developing and monitoring risk management policies in their specified areas. The risk management policies are established to identify and analyse the risks faced by the bank, to set appropriate risk limits and controls, and to monitor risks and adherence to limits. Risk management policies and systems are reviewed regularly to reflect changes in market conditions, products and services offered. It was also learnt that the bank is committed to developing a disciplined and constructive control environment, in which all employees understand their roles and obligations through training and management standards and procedures. This clearly shows that the bank is willing to commit resources to the risk mitigation process of the bank.

In order to follow the risk management framework, the bank has an audit committee in place which is responsible for monitoring compliance with the risk management policies and procedures, and for reviewing the adequacy of the risk management framework in relation to the risks faced by the bank. Specifically, in the management of market risks, the bank separates its exposure to market risk between trading and non-trading portfolios. Trading portfolios mainly are held by the brokerage subsidiary, and include positions arising from market making and proprietary position taking, together with financial assets and liabilities that are managed on a fair value basis. Nonetheless, overall authority for market risk is vested in ALCO while the Risk management department is responsible for the development of detailed risk 
management policies (subject to review and approval by the Board) and for the day-to-day review of their implementation.43.5.5. HFC Bank

Similar to the other banks, HFC is exposed to several risks risks such as; credit risk, liquidity risk, market risks, and operational risks. In terms of risk management structure, the Board of Directors has overall responsibility for the establishment and oversight of the risk management framework of the bank with other arms of risk control of the bank taking charge of specific risks.

HFC bank accounts for exposure to effects of fluctuations in the prevailing foreign currency exchange rates on its financial position and cash flows.

Foreign exchange rate risk Foreign exchange rate risk arises from changes in foreign exchange rates that affect the value of assets (primarily loans, overdrafts, advances and investments), liabilities (primarily, customer deposits) and off balance sheet transactions denominated in foreign currencies. Management develops procedures, instruments and control mechanisms designed to protect the value of the company's equity without endangering other business priorities. In addition, concentration of currency risk-on-and off balance sheet financial instruments is taken keenly by the bank on exposure to effects of fluctuations in the prevailing foreign currency exchange rates on its financial position and cash flows. As it is, the Board sets limits on the level of exposure by currency and in total for both overnight and intra-day positions, which are monitored daily.

\section{Summary, Conclusion and Recommendations}

The issue of exchange rate volatility vis-à-vis firm value or returns has gain much attention in recent times due to the exposure of firms as a result of the increasing risk in the global economy as well as those risks inherent in the Ghanaian economy owing to the recent foreign exchange rate risk being experienced in the country.

Through the application of the techniques used to achieve the main purpose of this paper and others purposes as; to assess the gains made by the banks from foreign currency trading over the study period, the banks' exposure to any major trading currency risk, and to find out how the banks manage their exchange rate risks, it was discovered that all the banks studied engage in forex trading and as such have made some gains/profits from such activities and as such appears to be a lucrative source of income for the banks. It was further shown that some of the banks are exposed to one form of foreign exchange risk or the other whiles others had no exposure at all. Specifically, apart from Ghana Commercial bank and Standard Chartered bank who were exposed to the pound sterling, the rest of the banks had no exposure to any of the currency risks.

Furthermore, the paper was able to discover that all the banks have risk management structure in place to mitigate any risks that arise as a result of their operations. All the banks have risk management frameworks in place with the board of directors having the highest responsibility for ensuring and overseeing the bank's risk profile. It was found that all the banks are faced with market risk/exchange rate risk and as such have in place adequate measures to check them. Some of them utilize currency swaps and forwards as derivative strategies. Overall, the banks have immense interest and desire to control risks through the identification, assessment and monitoring mechanisms put in place by all the banks as was found through this paper. Turning to the macroeconomic factors that affect firm exposure, it was unearthed that the inclusion of the interest rate and the market returns into the model does not impact the exposure of the banks to exchange rate risk.

The main purpose of this paper was to assess the exposure of some listed banks on the Ghana Stock Exchange to foreign exchange risk. From the results, we can conclude and say that in a whole only two banks (Ghana Commercial bank and Standard Chartered bank) are exposed to foreign exchange rate risk to the pound while the remaining ones are covered. Meanwhile, the forex market appears to be a very lucrative area for the banks as one of the sources of operating income. Additionally, all the banks except Standard Chartered bank is exposed interest rate risk. Nonetheless, the overall interest in risk management by the banks is very high and has put in some financial derivative measures to mitigate any exchange rate risk that they are exposed to.

\subsection{Recommendations for Implementation}

In-line with the outcome of this paper, we recommend that bank should take keen interest in covering their exposure in the UK pound and the US Dollar and should also cover their exposure in interest rate risk by employing a more appropriate derivative instrument if one is not already in place. Otherwise, adopt a prudent and contemporary interest rate risk management measure to limit their exposure.

\section{References}

[1] Abor, J. (2005), "Managing foreign exchange risk among Ghanaian firms", Journal of Risk Finance, Vol. 6, No. 4, pp. 306-18.

[2] AlDiab, T.F., M.M, Zoubi, and P.W. Thornton. (1994). The effect of changes in the dollar foreign exchange rate on stock returns of multinational corporations. Journal of Applied Business Research, Vol.10.

[3] Allayannis, G. and Ihrig, J. (2001), "Exposure and Markups", The Review of Financial Studies, Vol. 14, No. 3 (Autumn, 2001), pp. 805-835.

[4] Bhattarai, K. R. and Armah, M. K. (2005),"The Effects of Exchange Rate on the Trade Balance in Ghana: Evidence from Cointegration Analysis",Research Memorandum 52, August 2005,pp. 3-37. 
[5] Bodnar, Gordon and Gentry, William. (1993). Exchange-rate exposure and industry characteristics: evidence from Canada, Japan and U.S. Journal of International Money and Finance, 1993,12(1), pp. 29-45

[6] Bradley, K. and Moles, P. (2002), "Managing strategic exchange rate exposures: evidence from U.K. firms", Managerial Finance, Vol. 28, No. 11, pp. 28-42.

[7] Brunner, M., Glaum, M. and Himmel, H. (2000). The DAX and the Dollar: the economic exchange rate exposure of German corporations. Journal of International Business Studies, Vol 31, No 4, pp. 715-724.

[8] Carrieri, F. and Majerbi, B. (2006), "The Pricing of Exchange Risk in Emerging Stock Markets" Journal of International Business Studies, Vol. 37, No. 3 (May, 2006), pp. 372-391.

[9] Carrieri, F., Errunza, V. and Majerbi, B. (2006), "Does Emerging Market Exchange Risk Affect Global Equity Prices?", The Journal of Financial and Quantitative Analysis, Vol. 41, No. 3 (Sep., 2006), pp.511-540.

[10] Chang, Y. (2002). The Pricing of foreign exchange risk around the Asian Financial crisis: Evidence from Taiwan's

[11] Choi, J. J., Elyasiani, E. and Kopecky, K. J. (1992), “The sensitivity of bank stock returns to market: interest and exchange risks", Journal of Banking and Finance, Vol. 16, pp. 983-1004.

[12] Chow, E. H., Lee, W. Y. and Solt, M. E. (1997). The exchange-rate risk exposure of asset Returns. Journal of Business 70, 105-123.

[13] Chowdhry, B. (1995), "Corporate Hedging of Exchange Risk When Foreign Currency Cash Flow is Uncertain" Management Science, Vol. 41, No. 6 (Jun., 1995), pp. 10831090.

[14] Donnelly, R., and E. Sheehy. (1996). The share price reaction of U.K exporters to exchange rates movements: An Empirical study. The Journal of International Business Studies, Vol.27.

[15] Dufey, G. and Srinivasulu, S. L. (1983), "The Case for Corporate Management of Foreign Exchange Risk" Financial Management, Vol. 12, No. 4 (Winter, 1983), pp. 54-62.

[16] Dumas, B. (1978), "The theory of the trading firm revisited", Journal of Finance, Vol. 33, No. 3, pp. 1019-1029.

[17] Evans, Martin D., and Richard K. Lyons (2002), "Order Flow and Exchange Rate Dynamics," Journal of Political Economy, Vol. 102, pp. 170-180.

[18] Fang, H and J.C. Loo. (1994). Dollar value and stock returns. International Review of Economics and Finance, Vol.3.

[19] Jebuni, C. D. (2006), "The Role Of The Exchange Rate in Economic Policy Design and Analysis", CEPA Seminar Series on Macroeconomic Modeling and Public Accounts Management, Centre for Policy Analysis (CEPA), 22nd March, 2006.

[20] Jin Park, B. and Paul Choi, (2011), "Interest rate sensitivity of US property/liability insurer stock returns", Managerial Finance, Vol. 37, Iss: 2, pp. $134-150$.

[21] Jorion, P. (1990). The Exchange rate exposure of U.S. multinational. Journal of Business, Vol. 63 No: 3, 331-345.

[22] Jorion, P. (1991). The Pricing of Exchange Rate Risk in Stock Market, Journal of Financial and Quantitative

[23] Joseph, N.L. (2002). Modelling the impacts of interest rate and exchange rate changes on UK stock returns. Derivatives Use, Trading and Regulation, Vol. 7.

[24] Khoo, A. (1994), "Estimation of foreign exchange exposure: an application to mining companies in Australia", Journal of International Money and Finance, Vol. 13, pp. 342-63.

[25] Koutsoyiannis, A. (2001), "Theory of Econometrics", 2nd Edition, PALGRAVE, NY.

[26] Krishnamoorthy, A. (2001). "The impact of industrial structure and the exchange rate exposure of industry portfolio returns" Global Finance Journal, Vol.12.

[27] Logue, D. E. and Oldfield, G. S. (1977), "Managing Foreign Assets When Foreign Exchange Markets Are Efficient", Financial Management, (Summer 1977).

[28] Loloh, F. W. (2011), "Ghana: fiscal policy responsiveness, Persistence and discretion", Bank of Ghana Working Paper, WP/BOG-2011/10, pp. 2-23.

[29] Luehrman, T. A. (1991). Exchange Rate Changes and the Distribution of Industry Value. Journal of International Business Studies, 22, 619-649.

[30] Madura J. (2006), International Financial Management, 8th Edition.

[31] Miller, K. D. and Reuer, J. J. (1998a), "Firm Strategy and Economic Exposure to Foreign Exchange Rate Movements", Journal of International Business Studies, Vol. 29, No. 3 (3rd Quarter 1998), pp. 493-513.

[32] Miller, K. D. and Reuer, J. J. (1998b), "Asymmetric Corporate Exposures to Foreign Exchange Rate Changes" Strategic Management Journal, Vol. 19, No. 12 (Dec., 1998), pp. 1183-1191.

[33] Mintao, F. and Lyons, R. K. (2003) "Customer Trades and Extreme Events in Foreign Exchange," in Essays in Honor of Charles Goodhart, Paul Mizen (ed.), Edward Elgar: Notrhampton, MA, USA, pp. 160-179.

[34] Mishkin, F. (1996) "The Channels of Monetary Transmission: Lessons for Monetary Policy," NBER Working Paper, No. 5464, pp. 23-41.

[35] Nance, D., C. Smith \& C. Smithson. (1993). On the determinants of corporate hedging. Journal of Finance, Vol.48.

[36] Rosenberg, M. R. (2003), Exchange-Rate Determination: Models and Strategies for Exchange-Rate Forecasting, Mcgraw-Hill Professional.

[37] Salvatore, D. (1995), International Economics, Mcgraw-Hill Companies, Fifth Edition.

[38] Shapiro, A. C. (1974), "Exchange rate changes, inflation and the value of the multinational corporation", Journal of Finance, Vol. 30, No. 2, pp. 485-502.

[39] Stuart Hyde, (2007), "The response of industry stock returns to market, exchange rate and interest rate risks", Managerial Finance, Vol. 33 Iss: 9, pp. $693-709$. 
[40] Tongco, M. D. C. (2007), "Purposive Sampling as a Tool for Informant Selection" A Journal of Plants, People, and Applied Research, Vol. 5, pp. 147-158.

[41] Verschoor, W. F. C. and Muller, A. (2007), "The Asian crisis exchange risk exposure of US multinationals", Managerial Finance, Vol. 33, Iss: 9, pp. $710-740$.
[42] Yin, W. C., Chinn, M .D. and Marsh, I. W. (2000) "How do UK-Based Foreign Exchange Dealers Think Their Market Operates?" NBER Working paper, No. 7524, pp. 12-39.

[43] Zubeiru, Kofi \& Adjasi, K. (2007). Foreign exchange risk exposure of listed companies in Ghana. The Journal of Risk Finance Incorporating Balance Sheet, Volume 8, Number 4. 